\title{
Subject Index Vol. 19, No. 1, 1997
}

Dev Neurosci 1997;19:134

\author{
Subject Index Vol. 19, No. 1,1997
}

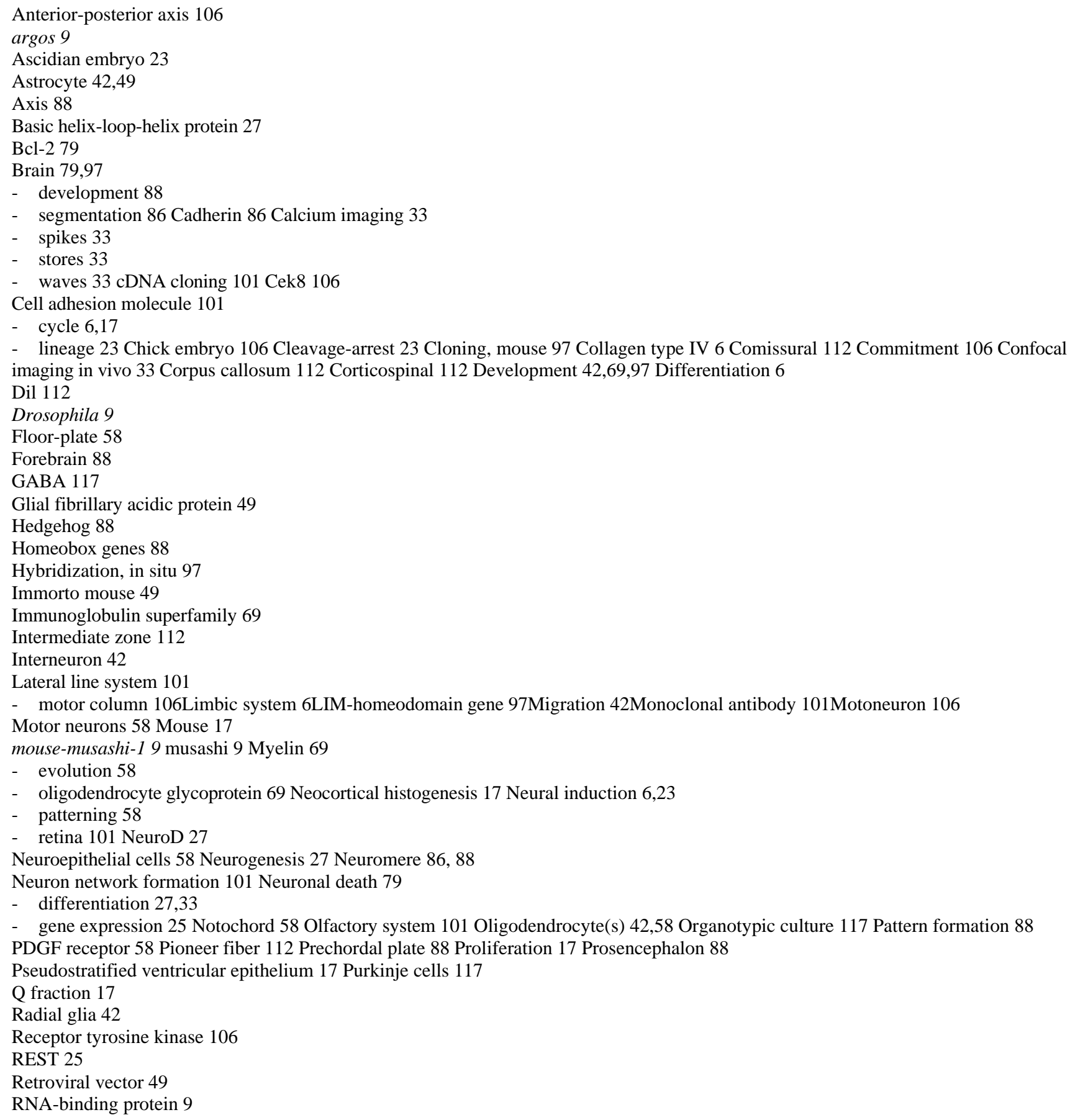


Sensory organ development 9

Silencer 25

Sonic hedgehog 58

Spinal cord 58

- neurons 33Spontaneous activity 33Subplate 112

Sub population 106 Transcription factor 27 Transcriptional repressor 25 Transforming growth factor alpha 6 Transgenic mice 69,79

Voltage-gated ion channels 23 Xenopus 101

\section{KARGER}

